\title{
A. An. vơ Chủ̉mmel's
}

\section{fämmtliche soerfe.}

\author{
$\mathfrak{F u ̈ n f t e r ~} \mathfrak{B} \mathfrak{a} \mathfrak{n}$.
}

\section{feipi $3^{i g}$.}

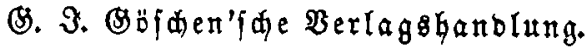

1853. 
